\title{
Research on Innovative Ways for Northeast Manufacturing Alliance
}

\author{
Jiaqi Chen \\ College of Economics and Law, Bohai University, Jinzhou, 121013, China \\ jackie@bhu.edu.cn
}

Keywords: technology alliance; technological innovation; manufacturing industry; automobile industry

\begin{abstract}
Technology alliance as a middle organization between market and enterprises organization forms, and it can meet the requirements of manufacturing for analysis, and can satisfy the demand of technology innovation of knowledge integration. In order to obtain better technological innovation ability, the enterprise can adopt longitudinal technical alliance with upstream and downstream enterprises, and it not only can effectively reduce the transaction costs in the process of knowledge fusion, but also can avoid the resulting from the integration of management costs and rising production costs. At the same time, enterprises can also horizontal alliance with competitors, it can expand the enterprise technology source, to reduce the risk of enterprise technology innovation and cost, increase the income of the enterprise technology innovation. Enterprise technology alliance, it also has reference significance in the development of automobile industry in Liaoning.
\end{abstract}

\section{Introduction}

The equipment manufacturing industry is a pillar industry of the northeast industrial, the revitalization of the northeast economy must be based on the revitalization of manufacturing, and manufacturing of the revitalization of the necessary, which is based on continuous technology innovation. In northeast of technological innovation in increasing capital investment at the same time, should also continue to explore how to further promote organizational innovation with technology innovation, and accelerate the pace of the revitalization of northeast manufacturing industry. Enterprise technology alliance as one of the core content of enterprise alliance, not only can improve the technical level of whole enterprise, but also can promote the enterprise technology innovation.

\section{Promoting Technological Innovation by Vertical Technology Alliance}

New product development as one of the important content of technology innovation, the success or failure depends not only on core status in the production chain of manufacturer's technical ability, but also depends on the raw material supplier's technical capabilities and sellers of information collection and processing capacity.

Supplier and is not only to the manufacturer to provide raw materials or intermediate products, should also is a good technical source of manufacturers, Williamson to the enterprise the asset specificity explanation will help us better understand this idea. Williamson in the book "the capitalist economic system", it is pointed out that the asset specificity can be divided into four categories: dedicated facilities, physical assets, human assets and special purpose, the four types of special assets constitute the special technology of enterprise. When manufacturers to develop new products, due to its new products on the production of the required raw materials and intermediate products without enough special assets, and therefore do not have complete technical ability. Therefore in the process of new product development, supplier and the manufacturer alliance can not only make up for the defect of manufacturers technical, but also can promote the fusion of different production technology, and provides a possible new production methods to produce.

To improve the efficiency of new product development, Japan's large manufacturing enterprise alliance with multiple suppliers, their only plays a role of coordination in the process of new 
product development or do only a small part of work, while the development of large parts, design, manufacture, sometimes even to supplier to complete the development work. This technique has the advantage of alliance, suppliers in the early stages of innovation process is involved in the innovation, this can promote knowledge sharing and integration between design and production, but also can greatly improve the efficiency of the development of new products, because quality control and timely delivery are guaranteed by the supplier. Like NEC, Fujitsu and Toshiba companies, generally only in the process of new product development for new products for five or six trials unit can start commercial production, because most of the necessary checks have been completed by the supplier. U.S. manufacturers, on the contrast, the information communication between design and production units and impeded, and manufacturers also often suffered from parts suppliers don't abide by the disciplines progress. IBM, often in the process of new product development to production of many of its parts, and usually needs to be done before new product commercialization production 100-150 experimental units.

In the process of technological innovation, from the market demand information is extremely important, because can timely market information in early correction technology the development direction of technology innovation, will be closely linked with the market demand for the development of new technology products, so the manufacturers and sellers technology alliance also has important significance.

In technological innovation happened on the way there have been two arguments: the market pull means that the new concept of service and commodity markets to seek new technology; Technology push is seeking applications for new technical ideas. But freeman is that technical innovation must consider these two factors, namely the technology innovation must be combined with market demand, and the view is accepted by more and more people. Markets are not always accept new technology products, due to disagree with market results in the failure of technological innovation also has a lot of, such as: IBM PCjz low-end computer, hand of the Go, computer, Data Play digital music products, Microsoft WEB TV and so on.

Since the technology innovation requires manufacturers and suppliers and distributors alliance, whether take the integration of organizational form will be better? The answer is no.

Williamson argues that why people make a vertical integration decision-making is not for reasons of production technology, but a integration can save transaction cost. Due to exchange the asset specificity, uncertainty and transaction frequency will affect the transaction costs, especially caused by asset specificity opportunistic behavior will substantially increase the transaction cost, thus through vertical integration will be the internalization of external trade, which can reduce the transaction costs. Although vertical integration can reduce the transaction cost, but after the integration will bring other costs rise, it mainly includes: enterprise supply factors of production for yourself or for selling their products competitive in the market is likely to be higher than the cost of dedicated to provide these services in the middle of the enterprise's cost; May bring enterprise scale uneconomical scale, management costs; Enterprises in the integration process has to spend a lot of costs.

As organization between market and enterprise internal organization between a form of organization, enterprise technology alliance can not only effectively reduce the transaction cost in the process of knowledge fusion, but also can avoid the resulting from the integration of management costs and rising production costs. Therefore, the enterprise longitudinal technical alliance can effectively promote the generation of technology innovation.

\section{Promoting Technological Innovation by Horizontal Technology Alliance}

Enterprise's external technology sources are not limited to is closely related to enterprise production suppliers and vendors, should also include those specializing in new technology research and development of scientific research institution and the competition of the enterprise, through the appropriate way to these units form a transverse technology alliance, to accelerate the technological innovation of enterprises has very important significance.

Enterprises and research institutions formed a technology alliance, it is not just to use the 
scientific research institutions to create new knowledge, more important is to should make through this alliance enterprise out of the "leading technology trap".

Enterprise without core technology is dangerous, because such companies will be defeated by competitors, powerful technical strength, but companies to master advanced technology is also dangerous, companies are often trapped in his construction of "leading technology trap" is difficult that extricate themselves. When the enterprise has a leading technology, it will be on the basis of the advanced technology to develop new technology products as much as possible, and through the patent system to leading technology and related products for the strict protection. With the deepening of enterprise of the technology research, related to new product new technology will be more and more, the dominant position in the enterprise in the direction also will be more and more cement, but at the same time the enterprise change the direction of technology development will be increasingly difficult. A lot of money and personnel, rich technical knowledge accumulation, will become the enterprise technology development of sunk costs. In subsequent technological innovation, how to make full use of the sunk costs will become the guiding ideology of enterprise technology innovation, enterprise and so on the advanced technology for the formation of path dependence, will be far from the market demand is more and more new products, and gradually lose innovation properties. Strict patent system while protecting the enterprise's current interests, but also force other enterprise another stream diameter, develop more advanced technology, and the enterprise in the "leading technology" all efforts were in tatters. As France build the Maginot line, force Germany to choose new attack path, will eventually France solid defend line into scrap metal.

Xerox in 1949 launched the first electrostatic copier in human history, has always tried to keep the leading position in the copier technology. During the later development, a lot of new technology derived from Xerox for "and the relationship between primary production line (PPC) than other projects closely" and abandoned, and missed opportunities. Xerox invented the world's first PC, but it is the first IBM PC market; Xerox first use the mouse to click the graphical interface, but Microsoft on your WINDOWS system; Xerox invented the "Wysiwyg" WORD processor, but they are used by MICROSOFT to MICROSOFT WORD. In the market for copiers, Xerox numerous technology patents has not stopped a competitor's attack, Ricoh, Canon and other companies have become the strong competitors. In the field of laser color printing, Xerox's market share has fallen behind others HP and Lexmark. Xerox is in the "leading technology trap" constructed gradually sinking.

Enterprise with scientific research institution alliance will not only expand enterprise sources of technology, and research institutions for the exploration of cutting-edge knowledge, will help enterprises to establish the correct technology development direction, prevent enterprise in the "leading technology trap" deeper.

Japanese enterprise attaches great importance to scientific research institution alliances. When into an unfamiliar area, Toyota will with scientific research institution (university or research institute), an alliance. Toyota's researchers can go do some of their work in the university, professor with the university's many has a very free to contact. Toyota 30-60 each year the researchers and engineers have the opportunity admitted to university alliance. Toyota's Lexus is by California's Calty design institute and design centers in Europe and Japan design successful cooperation.

Companies formed an alliance with competitors, not only can share the risk of technological innovation, but also can accelerate the technology diffusion, and profit from it.

For enterprises who want to get paid through technical innovation lead, they will face greater risks in the technological innovation, the bigger the risk and the more complicated technology. Schumpeter believes that pioneer always must get rid of difficulties. For imitators, however, they can follow others and once upon a time people learning from mistakes, so can get success in business, and technology innovators create new market will be strong market capacity and production capacity of technology followed by occupation. So when making large-scale technical innovation, with rival alliance can not only realize the power-and-power union, but also can spread risk and innovation costs. 
With rival alliance phenomenon in today's increasingly commonplace. SONY in 1995 and former rival Siemens company cooperation to develop a new generation of mobile phones; Alliance with Samsung electronics, Philips development broadband TV reception system; With HP, Mitsubishi, Philip, Ricoh, Yamaha and other large companies alliances, joint development rewritable optical disc technology. Toyota and ford cooperative research development speed control system; Cooperate with Hino development off-road vehicle; And del motor company alliance, joint development of automotive electromagnetic induction loading system.

In short, horizontal technology alliance development technical resources of the enterprise, and reduce the enterprise technology innovation risk and cost, increased the income of enterprise technology innovation, so it can effectively promote the generation and diffusion of technology innovation.

\section{Northeast Manufacturing Enterprises Need Technical Alliance}

Manufacturing industry is the pillar industry of northeast, but less northeast manufacturing performance. Such as Liaoning manufacturing compared with the seven major economic benefits, total assets accounted for $4.36 \%$, only $68.8 \%$ of the national average; Assets tax rate is $2.75 \%$, only $54.03 \%$ of the national average; Output tax rate is $4.99 \%$, only $78.34 \%$ of the national average; Per capita profit tax is 3755 yuan, is the national average of $53.11 \%$; Overall Labour productivity of 19140.21 yuan, the national average of $68.03 \%$.Cause such results are various, and technology backwardness is one of important reasons, so the revitalization of northeast China manufacturing, have to rely on technological innovation. In Liaoning province automobile industry, for example, only talk about how to promote industrial technology innovation by building enterprise technology alliance.

Liaoning existing automobile production enterprises, more than 140, of which there are nine, car modification, car manufacturing enterprise of the 48, six special engine manufacturing enterprises, 80 auto parts enterprises. Despite having a large enterprise, but enterprises generally on a smaller scale, the low level of technology, technological innovation ability is poorer, product homogeneity is very serious.

Auto production enterprise profitability is the main reason of the enterprise's technological innovation ability is low, lead to enterprise serious product homogeneity, corporate earnings can only rely on the increase of market demand, so the demand shrinks, earnings decline. Enterprise's technology innovation ability is low also makes the enterprise product lacks enough in the international market competition. In many auto parts enterprises, products exported to the foreign enterprise will only 13, and annual export amount less than \$20 million. Can improve enterprise technology innovation, therefore, to improve the competitiveness of the enterprise products, is the most important of the Liaoning automobile manufacturing enterprises to solve problems.

Through mergers and acquisitions among enterprises realize Liaoning auto production enterprise assets reorganization, is a good way to improve the innovative capability of enterprise technology, but it depends on whether as a decline in the cost of the enterprise after merger can offset and management costs rise and the increased cost of mergers and acquisitions. Technology alliance between enterprises, in contrast, not only can improve the technological innovation ability of enterprises, but also could not increase the cost of management and acquisition costs. So car manufacturers and suppliers (auto parts enterprise technology alliance, is Liaoning auto production enterprises to improve technology innovation ability of the optimal choice.

Liaoning education resources are rich, strong scientific research ability, there are 66 ordinary colleges and universities, they should be Liaoning auto production enterprises one of the most main source of technology. At present, Liaoning has 35 companies cooperation with northeastern university (long-term cooperation is the union), including "sac", "heavy", "Shenyang XinGuang aerospace " and "Anshan iron and steel", "Benxi steel, and other enterprises. Where "Fushun special steel" and "university" set up the team for tackling key problems and benefits in 2003 than in 2002, an increase of 215 million yuan; Signed with Anshan "neusoft" super hot rolled ribbed steel wires cooperative development projects, technology reached the international advanced level. Therefore 
and university research institutions formed a technology alliance, is Liaoning automobile manufacturing enterprises to keep continuous technology innovation ability the important way.

\section{Conclusion}

By vertical alliance and horizontal alliance, enterprises can solve the contradictions of has plagued the enterprise organization structure, namely manufacturing organization demands for specialization and technological innovation organization more knowledge fusion of contradictions. At the same time, the enterprise alliance also enables enterprises to effectively reduce the transaction costs in the process of knowledge integration, reduced the enterprise technology innovation risk and cost, increased the income of enterprise technology innovation, so it can effectively promote the generation and diffusion of technology innovation, improve the efficiency of innovation.

\section{References}

[1] Oliver Williamson, "Capitalist economic system," Commercial press, pp. 67-77, 2002.

[2] Z. A. Yuan, "Enterprise alliance," Shanghai people's Publishing House, pp. 124-127, 2002.

[3] West Gefade Harrison, "Japan's technology and innovation management," Peking University press, pp. 118-137, 2004.

[4] William Baumol, "The growth miracle of capitalism," China Citic Press, pp. 87-92, 2004.

[5] Jonh Bessant, "High-Involvement Innovation," John Wiley \& Sons Ltd, pp. 26-35, 2003.

[6] Day moss Maurice SUZUKI, "Japan's technological change," China Economic Publishing House, pp. 59-76, 2002. 